Eckblad, F.-E., 1955: The Gasteromycetes of Norway. The Epigaean Genera. - Nytt Mag. f. Bot., 4, 19-86.

$\longrightarrow$ - \& Wrschman, F., 1953: To for Norge nye Phallaceer. - Blyttia 11, $133-139$.

FAegri, K., 1948: Funn av Mutinus caninus i Norge. - Friesia 3, 331-332.

Ferdinandsen, C. \& Winge, O., 1943, Mykologisk Ekskursionsflora. 428 pp. - Ciopenhagen.

Gertz, O., 1923: En ny fyndort i Skåne för Phallus caninus Huds. - Botaniska Notiser 114, 241-244.

Holgersen, H., 1951: To nye funn av liten stinksopp (Mutinus caninus). Naturen $75,190-191$.

Holmberg, U., 1961: Intressanta svampar i Kristianstadstrakten. - Botaniska Notiser $114,241-244$.

HöJer, J., 1951: Dictyophora duplicata i Värmland. - Sv. Bot. Tidskr. 54, 530.

INGELSTRÖM, E., 1940: Svampflora. 216 pp. - Stockholm.

Jørstad, I., 1944: Notes on Norwegian Fungi. 1-3. - Blyttia 2, 33-36.
LAINE, U.,

1955: Haisusienen (Phallus impudicus (L.) Pers.) viimeaikaisesta esiintymisestä Varsinais-Suomen pohjoisosassa. - Luonnon Tutkija $59,8-11$.

Luther, H., 1947: Beobachtungen über Phallus impudicus (L.) Pers. in Finnland. - Mem. Soc. F. Fl. Fenn. $23,42-59$.

Malmström, N., 1941: En för Finland ny Peziza, P. Acetabulum L. - Mem. Soc. F. F1. Fenn. 17, 189-191.

Neuhoff, W., 1956: Die Milchlinge. - Die Pilze Mitteleuropas II b.

Schulmann, O., 1960: Zur Kenntnis der Basidiomyceten Finnlands. - Karstenia V, $5-99$.

Skottsberg, G., 1936: Anthurus australiensis, en för Norden ny Phalloidé. - Medd. Göteborgs Bot. Trädgård 11, $135-157$.

Winter, G., 1884: Die Pilze Deutschlands, Oesterreichs und der Schweiz. I. Abt. - Rabenhorst's KryptogamenFlora, Leipzig.

\title{
Notes on Finnish Myxomycetes
}

\author{
V. Hintikka
}

During the years 1954-62 I have made some occasional collections of Myxomycetes chiefly in Helsinki parish (about $24 \mathrm{~km} \mathrm{~N}$ of Helsinki). Of the species listed below, Physarum psittacinum Ditm. has not been previously recorded from Finland. Dried specimens are preserved in the Botanical Museum of the University of Helsinki and in the Herbarium of Forest Research Institute of Finland.

Ceratiomyxa fruticulosa Macbr. - After long periods of rain not uncommon on rotten wood. Collected in 1959, -58 and -62 .

Physarum psittacinum Ditm. - Helsinki parish, Korso, on mosses, in a rich swamp 9.8.1960. According to R. FRIEs (1912) this species has in Sweden been recorded from several localities.

Physarum viride Pers. - Helsinki, Västersundom, on a rotten stump in a grass-herb-forest, 11.8.1960.

Physarum nutans Pers. - Met with twice on decayed wood in Korso.

Fuligo septica Gmelin - Common in the neighbourhood of Korso.

Leocarpus fragilis Rost. - Fairly common in Korso (8 collections), collected also in Lk: Sodankylä village, 7.8 .58 .
Didymium melanospermum Macbr. - 10 collections from Helsinki parish.

Mucilago spongiosa Morgan - Kerava, Ali-Kerava, on dead shoots of Populus in a herb-rich forest, 9.9.56.

Comatricha nigra Schroet. - Helsinki parish, Simonkylä, on a rotten stump in swampy spruce forest, 12.8.1960.

Lamproderma violaceum (Fr.) Rostk. - Tuusula, Hyrylä, on living stems of Vaccinium myrtillus, 14.5.55. Amaurochaete fuliginosa Macbr. - Korso, on a pine split billet, 26.8.46, on a old pine stump 20.7.54.

Tubifera ferruginosa Gmel. - Helsinki parish and Tuusula, Ruotsinkylä, not rare on old stumps.

Lycogala epidendron Fr. - Very common.

Trichia favoginea Pers. - Tuusula, on a old stump in swampy spruce forest rich in ferns.

Trichia decipiens Macbr. - Collected 5 times on rotten stumps.

Trichia Botrytis Pers. - Nurmijärvi, Raala, in a rich swamp on the bark of a fallen spruce, 29.1.60. Arcyria incarnata Pers. - Korso, on rotten wood, 15.9.60.

Arcyria nutans Grev. - Met with several times on old stumps and logs.

Literature. - Fries. R. E., 1912: Den svenska Myxomycet-floran.-Sv. Bot. Tidskr. 6, 721-802. 